\title{
Flipping the Question: \\ The Reception of EU Law in the International Legal Order
}

\author{
Ramses A. Wessel* \\ Draft - To be published in Oxford Yearbook of European Law, 2016
}

\section{Introduction}

This paper is not the first in addressing the relationship between international and EU law. In fact, and as also noted in the Introduction to this Special Issue, ever since Van Gend \& Loos the 'autonomy' of the Union (by then the Community) proved to be a source of theoretical debates on the issue. ${ }^{1}$ Studies focussed on the ways in which international law was received in the Union's legal order (often applying domestic constitutional analogies involving terms such as monism and dualism), or they addressed the hierarchical position of international law among other norms (often concluding that it was placed somewhere between primary and secondary law). In other words, most studies so far have focused on the effects of international law on and in the EU and the question to which extent the EU could be said to be bound by international norms. ${ }^{2}$

Yet, the coming of age of the EU as a global actor may slowly turn the EU from a recipient into a contributor to the further development of international law. Already ten years ago the European Commission stated that 'the EU is emerging as a global rule maker, with the single market framework and the wider EU economic and social model increasingly serving as a reference point in third countries as well as in global and regional fora'. ${ }^{3}$ And, since the Treaty of Lisbon

* Professor of International and European Law and Governance, Centre for European Studies, University of Twente, The Netherlands. Parts of this paper were written as a Visiting Professor at Sapienza - University of Rome. Earlier versions of this Chapter were presented at different conferences and seminars. The author is indebted to all colleagues sharing their valuable thoughts during those sessions.

${ }^{1}$ Among the many publications on the autonomy of the EU, allow me to mention just one, because it is comprehensive, recent, and contains many references to the earlier publications: T Molnár, 'The Concept of Autonomy of EU Law from the Comparative Perspective of International Law and the Legal Systems of Member States' (2015) Hungarian Yearbook of International Law and European Law 433-459.

${ }^{2}$ See, for example, E Cannizzaro, P Palchetti and RA Wessel (eds.), International Law as Law of the European Union (Martinus Nijhoff 2011); RA Wessel, Close Encounters of the Third Kind: The Interface Between the EU and International Law after the Lisbon Treaty, (Sieps Report 2013), 106 pp.

${ }^{3}$ Commission staff working document, The External Dimension of the Single Market Review, SEC(2007)1519, 20 Nov. 2007, at p. 5. 
in particular, the EU treaties clearly reveal the EU's global ambitions in this area, which basically boil down to the idea that the EU should - at least partly - shift its focus from its own Member States to third countries ${ }^{4}$ - thereby even limiting the possibilities for its own Member States to contribute on their own to international law-making. ${ }^{5}$

Thus, the question addressed in this paper is not how international law is received by the EU, but how EU law is (or could be) received by the international legal order. In other words: to what extent can EU law form a source of international law? In that sense this article aims to contribute to an essential element of the theme of this Special Issue, namely the 'formative influence ${ }^{6}$ of the European Union on public international law. This question has hardly been addressed in literature, which indeed largely deals with the question to which extent international law can be a source of EU law. ${ }^{7}$

Again phrased otherwise, this contribution is not about the effects of international law, but about the effects on international law. So, where the question of the 'Europeanisation of international law' is usually understood as dealing with the way in which international law is 'Europeanised' when it becomes part of the EU legal order (leading to questions on the emergence of a distinct European system of international law or the consequences of this 'Europeanisation' for the unity and coherence of public international law), ${ }^{8}$ this article aims instead to assess the way in which international law is 'Europeanised' outside the EU as well as the extent to which this is possible. ${ }^{9}$ The question of whether this is desirable is left aside, but has occasionally also been addressed in academic literature. ${ }^{10}$

\footnotetext{
${ }_{5}^{4}$ See in particular Arts. 3(5), 21 and 22 TEU.

${ }^{5} \mathrm{P}$ Koutrakos, 'In Search of a Voice: EU Law Constraints on Member States in International Law-Making', in R Liijova and J Petman (eds.), International Law-Making: Essays in Honour of Jan Klabbers (Routledge 2014) 211-224.

${ }^{6}$ See the introduction to this Special Issue by P Gragl and V Moreno-Lax.

${ }^{7}$ A recent exception may be the interesting and extensive study by $\mathrm{J}$ Odermatt, The European Union as a Global Actor and its Impact on the International Legal Order, $\mathrm{PhD}$ thesis, University of Leuven, 2016. This study claims that '[r]ather than examining international law's shaping of EU law and the development of its legal order, a different question is posed. How does international law deal with the EU?' (at p. 17). Yet, here also, large parts deal with the question of how the EU fits in or how international law is applied within the EU. Another recent study addressing the way in which EU law may contribute to international law is by P Nevill, 'The European Union as a Source of Public International Law' (2013) Hungarian Yearbook of International Law and European Law 281-295 (Eleven International Publishing 2014). Focusing specifically on international customary law and its 'reception' within the EU legal order, see Theodore Konstadinides' contribution to this Special Issue.

${ }^{8}$ See J Wouters, A Nollkaemper and E de Wet (Eds.), The Europeanisation of International Law: The Status of International Law in the EU and its Member States (T.M.C. Asser Press 2008).

${ }^{9}$ Compare the well-known remark made by the Italian Constitutional Court in the 1970s, when it claimed that '[f]undamental requirements of equality and legal certainty demand
} 
By now the EU has a legal relationship with almost all States in the world and it is an active participant in many international organizations (either directly or through its Member States). It has been held that the EU is a global normative actor, ${ }^{11}$ in particular in the promotion of its own values and by influencing global policy-making. Yet, influencing policies is not the same as influencing legal norms. International law is known for its quite strict rules on what it considers to be a legitimate source. The question is, therefore, to which extent EU practice may indeed contribute to international law-making. ${ }^{12}$

The next section will first of all map the EU's global ambitions in this area, by highlighting the relevant provisions in the Treaties, as well as in other documents. References to relevant case law will also be included (Section 2). Section 3 will then investigate the possible ways in which the EU may influence international law. This will be followed by a short theoretical analysis in Section 4 of possible ways in which EU law could serve as an actual source of international law. Section 5 will be used to draw some conclusions.

that the Community norms,... cannot be characterised as a source of international law, nor foreign law, nor of internal law of the individual States...'; Frontini v. Ministero Delle Finanze, Case 183/73 Italian Constitutional Court [1974] 2 CMLR 372.

${ }^{10}$ See, on the idea of the EU as a 'model' for the international legal order, for instance, A Cassese, 'Towards a Moderate Monism: Could International Rules Eventually Acquire the Force to Invalidate Inconsistent National Laws?', in A Cassese (ed.), Realizing Utopia: The Future of International Law, (OUP 2012), at 187; A Slaughter and WW Burke-White, 'The Future of International Law Is Domestic (or, The European Way of Law)' (2006) 47 Harvard International Law Journal 327-352, at 327; M Weller, 'The Struggle for an International Constitutional Order', in D. Armstrong (Ed.), Routledge Handbook of International Law, (Routledge 2009), 179-194, at 181. It has even been suggested that 'the European example is now most often cited by international lawyers not by way of contrasting public international law regimes but by way of suggesting the probable or desired trajectory of some of the more specialized international law regimes'. See JE Alvarez, International Organizations as Law-Makers, (OUP 2006), at 468.

${ }^{11}$ See, for instance, I Manners, 'Normative Power Europe: A Contradiction in Terms?' (2002) 40 JCMS 235-258; H Sjursen, 'The EU as a Normative Power: How Can This Be?' (2006) 13 JEPP 235-151; R Whitman (ed.), Normative Power Europe: Empirical and Theoretical Perspectives (Palgrave, 2011); and T Forsberg, 'Normative Power Europe, Once Again: A Conceptual Analysis of an Ideal-type' (2011) 49 JCMS 11831204, at 1183. See also some chapters in N Witzleb, A Martínez Arranz, P Winand (eds.), The European Union and Global Engagement: Institutions, Policies and Challenges, (Edward Elgar 2015). See for a critical assessment of political theories on this point, for instance, H Sjursen, 'Normative Theory: An Untapped Resource in the Study of European Foreign Policy', in KE Jørgensen, ÅK Aarstad, E Drieskens, K Laatikainen and B Tonra (eds.), The SAGE Handbook of European Foreign Policy, Vol. 1 \& 2, (Sage 2015) $197-213$.

${ }^{12}$ See also the extensive contribution by F Hoffmeister, 'The Contribution of EU Practice to International Law', in M Cremona (ed.), Developments in EU External Relations Law, (OUP 2008) 37-127. 


\section{The EU's Ambitions as a Global Rule-Maker}

Article 3(5) TEU is quite clear on the notion that the EU's role is not limited to internal law-making:

In its relations with the wider world, the Union shall uphold and promote its values and interests and contribute to the protection of its citizens. It shall contribute to peace, security, the sustainable development of the Earth, solidarity and mutual respect among peoples, free and fair trade, eradication of poverty and the protection of human rights, in particular the rights of the child, as well as to the strict observance and the development of international law, including respect for the principles of the United Nations Charter. ${ }^{13}$

In doing so, the European Union seeks inspiration in its own development. Article 21(1) TEU provides:

The Union's action on the international scene shall be guided by the principles which have inspired its own creation, development and enlargement, and which it seeks to advance in the wider world: democracy, the rule of law, the universality and indivisibility of human rights and fundamental freedoms, respect for human dignity, the principles of equality and solidarity, and respect for the principles of the United Nations Charter and international law.

References to international law can be found throughout the Treaties. The same holds true for the United Nations. In fact, the attention to the United Nations and its principles in the EU Treaties is overwhelming; the United Nations is referred to 19 times in the current EU Treaties (including the Protocols and Declarations). ${ }^{14}$ The EU obviously regards many of its actions as being part of a global governance programme. Since 1990, a Council Working Group on Public International Law (COJUR) has been involved in international law questions related to the EU's policies. ${ }^{15}$ It brings together legal experts from the Member States (mostly the Foreign Ministry's Legal Advisers) and the Legal Advisers of the Institutions. While COJUR can be used for an exchange of views on international legal issues, it may also prepare the view of the EU as such on matters of public international law. ${ }^{16}$

\footnotetext{
${ }^{13}$ Emphasis added.

${ }^{14}$ See for instance Arts. 3(5), 21, 34, 42 TEU, Preamble TFEU, Arts. 208, 214, 220 TFEU as well as some Protocols and Declarations.

15 http://www.consilium.europa.eu/en/council-eu/preparatory-bodies/working-partypublic-international-law/.

${ }^{16}$ Hoffmeister (n 12) at 50-51.
} 
Going back in time, 'Europe' has of course always played a large role in international law-making. The question whether international law is a European invention forms the source of extensive academic debates. ${ }^{17}$ These debates, however, focus on the role of European States in international law-making, whereas the present contribution aims to look at the role of the European Union itself. Over the years, this distinct level of governance and law-making not only obtained its own internal dynamic, but it has been argued that the EU equally put its mark on the development of key areas of international law, including policy areas such as international trade, finances, and the environment. ${ }^{18}$

It remains important to underline that irrespective of the clear link between many internal and external policies, ${ }^{19}$ the Union has a choice to participate in either international law-making or to legislate domestically. In the words of De Witte and Thies: 'the competence allocation under the Treaties does not distinguish, in principle, between internal and external competences of the EU and therefore does not establish any "venue preference". In other words, where the EU has competence to legislate, it can do so in any accessible venue'. ${ }^{20}$ Yet, as also underlined by these authors, there may be legal constraints. While internal legal constraints flow for the rules and principles in the EU Treaties, external constraints are related to the fact that the Union, as a non-state actor, may have limited access to traditional international law-making procedures and fora. An interesting effect, however, is that law-making at the global level may trigger increased activity of the Union in that area, and vice versa. De Witte and Thies described this in terms of upstream and downstream 'sequencing', pointing to and ever-stronger interaction between internal and external policy-making. ${ }^{21}$ Thus, international agreements may trigger new legislation at EU level (for instance, in the area of food safety, private international law, or the rights of disabled persons), which in turn strengthens the international role of the Union in these

\footnotetext{
${ }^{17} C f$. M Koskenniemi, 'International Law in Europe: Between Tradition and Renewal' (2005) 16 EJIL113-124; A Orakhelashvili, 'The Idea of European International Law', EJIL, 2006, p. 315.

${ }^{18}$ See the various contributions to B Van Vooren, S Blockmans and J Wouters (Eds.), The EU's Role in Global Governance: The Legal Dimension (OUP 2013).

${ }^{19}$ See for instance M Cremona, 'The External Dimension of the Single Market: Building (on) the Foundations' in C Barnard and J Scott (Eds.), The Law of the Single European Market: Unpacking the Premises (Hart Publishing 2002); or the other way around: C Eckes 'External Relations Law: How the Outside Shapes the Inside', in D Acosta Arcarazo and CC Murphy (eds.), EU Security and Justice Law: After Lisbon and Stockholm (Modern studies in European law, 42; Hart Publishing, 2014) 186-206.

${ }^{20} \mathrm{~B}$ De Witte and A Thies, 'Why Choose Europe? The Place of the European Union in the Architecture of International Legal Cooperation', in B Van Vooren et al. (n 18)23-58 at 34 .

${ }^{21}$ Ibid., at 36 .
} 
areas in discussions on implementation or revision of agreed rules, principles, or standards. $^{22}$

All in all, the global ambitions of the EU are clear and the next question is in which ways the EU may put its mark on the further development of international law.

\section{Influencing Public International Law}

\subsection{The use of international agreements}

Obviously, the most common way of the EU to influence international law, or to contribute to it, is by concluding an international agreement. ${ }^{23}$ At least in the eyes of the EU itself, it has been influential on changing the rules of the game: '[b]ecause of the regularity with which it is admitted to participate in multilateral treaties the European Union has shaped treaty law and practice in a significant manner'. ${ }^{24}$

Treaties, indeed, form a key source of international law. Notwithstanding the absence of a definition of 'international agreements' in the EU Treaties (or perhaps exactly because of this), it is obvious that the term should be read in its international context and thus the international law definitions apply. The international agreements concluded by the EU can be said to follow the description in Article 2(1)(a) of the Vienna Convention on the Law of Treaties, ${ }^{25}$ and are therefore 'treaties' in the sense of the Vienna Convention. ${ }^{26}$ The same

\footnotetext{
${ }^{22}$ More extensively on this interaction: RA Wessel and J Wouters, 'The Phenomenon of Multilevel Regulation: Interaction between Global, EU and National Regulatory Spheres' (2007) 4 International Organizations Law Review 257-289.

${ }^{23}$ Cf. J Klabbers, 'Straddling the Fence: The EU and International Law', in A Arnull and D Chalmers (eds.), The Oxford Handbook of European Union Law (OUP 2015) 52-71 at 53: "the EU has concluded a large number of treaties and so contributes generously to the solidification and development of the law of treaties".

${ }^{24}$ Statement on behalf of the European Union by Lucio Gussetti, Director, Principal Legal Adviser, European Commission, at the UN General Assembly 6th Committee (Legal) 66th Session: Report of the International Law Commission on the work of its sixty-third session on Responsibility of International Organisations, 24 October 2011, New York. See Odermatt (n 7) at 208.

${ }^{25}$ Vienna Convention on the Law of Treaties, 1155 U.N.T.S. 331, 8 I.L.M. 679, entered into

force Jan. 27, 1980. Art 2(1)(a) VCLT states that: “Treaty" means an international agreement concluded between States in written form and governed by international law, whether embodied in a single instrument or in two or more instruments and whatever its particular designation'.

${ }^{26} \mathrm{Cf}$. K Schmalenbach 'Article 27. Internal law and observance of treaties', in O Dörr, K Schmalenbach (eds), Vienna Convention on the Law of Treaties: A Commentary (Springer 2012) 456-7: "From the viewpoint of international law, it can be argued the
} 
may hold true for international contractual obligations that have not been given the heading of 'international agreement', but bear labels such as 'Convention' or 'Memorandum of Understanding'. Agreements may also be concluded in the form of an exchange of letters. As long as the parties agree that they enter into a legal commitment, the EU Treaty procedures apply. This has been confirmed by the Court when it described an international agreement as 'any undertaking entered into by entities subject to international law which has binding force, whatever its formal designation'. ${ }^{27}$ The fact that the 1969 Vienna Convention refers to States only is solved by the 1986 Vienna Convention on the Law of Treaties between States and International Organizations and between International Organizations, ${ }^{28}$ which contains a similar definition, taking into account the fact that international organizations may also conclude treaties. ${ }^{29}$ Although the concluding procedure is 'governed by EU law' (as the conclusion of treaties between States is usually regulated in domestic law), there is no doubt that the final agreement between the EU and a third state or international organization is governed by international law.

As a matter of EU law, the competence to conclude international agreements is undisputed. ${ }^{30}$ The EU is a party to well over 1,000 treaties. ${ }^{31}$ With the increasing internal competences the scope of the Union's legal dealings with third States was extended to almost all areas covered by the Treaties. The EU's Treaties Database thus lists international agreements in the areas of Agriculture, Coal and Steel, Commercial Policy, Competition, Consumers, Culture, Customs, Development, Economic and Monetary Affairs, Education, Training, Youth, Energy,

TEU and the TFEU (and the secondary rules derived from it) are still international treaties pursuant to Art 2 lit a VCLT irrespective of whether they have direct effect within the Member States legal orders. The qualification as international law, however, does not argue against its concurrent character as 'internal law' in terms of Art 27 (and Art 46), given that the national legal order allows supranational law to be just as directly applicable and effective as internal law." On the 'gap-filling' function of international customary rules, as those enshrined in the VCLT, within the EU legal order, see Theodore Konstadinides' contribution to this Special Issue.

${ }^{27}$ See Opinion 1/75 Re Understanding on a Local Cost Standard [1975] ECR 1355. See also Case C-327/91 France v Commission [1994] ECR I-3641, para 27.

${ }^{28} 25$ ILM 543 (1986) / Doc. A/CONF.129/15. This Treaty is not yet in force and the EU is not a party. Therefore the relevant rules of customary international law would apply to the EU as an international legal subject.

${ }^{29}$ See Art. 2: "“treaty" means an international agreement governed by international law and concluded in written form: (i) between one or more States and one or more international organizations; or (ii) between international organizations, whether that agreement is embodied in a single instrument or in two or more related instruments and whatever its particular designation;'

${ }^{30}$ Cf. Opinion 1/2003, Lugano Convention, [2006] ECR I-1145: "whenever Community law created for the [EU] institutions powers within its internal system for the purpose of attaining a specific objective, the Community has authority to undertake international commitments necessary for the attainment of that objective even in the absence of an express provision to that effect."

31 See the Treaties Office Database of the European External Action Service http://ec.europa.eu/world/agreements/default.home.do. 
Enlargement, Enterprise, Environment, External Relations, Fisheries, Food Safety, Foreign and Security Policy, Fraud, Information Society, Internal Market, Justice, freedom and security, Public Health, Research and Innovation, Taxation, Trade, and Transport. Numbers range from 134 agreements in the trade area to 1 on culture. At the same time - and as further developed below - international treaty law allows the EU to fit in an international system which is mainly composed of States. Despite the fact that the EU is not a party to the Conventions on the Law of Treaties or on Diplomatic and Consular Relations, ${ }^{32}$ it often choses to 'contract in' by simply adopting existing international legal regimes, for instance in relation to its own diplomatic activities or its privileges and immunities. ${ }^{33}$

Both bilateral and multilateral agreements form a source of international law and, as a major global player, the EU may substantially influence the text of an agreement. Yet, the question may be rightfully posed whether this can be seen as EU law forming a source of international law. After all, in many cases, substantive EU law may not exist at the time of the negotiations and the EU is simply one of the parties. Thus, we have seen an active role by the EU in such diverging areas as security, environmental policies, financial governance, or migration. $^{34}$

In certain areas, the EU may wish to 'export' existing EU law, in particular to prevent conflicts between EU and international law. ${ }^{35}$ It is well know that, for instance, the Marrakesh Agreement, ${ }^{36}$ which forms the basis for the WTO, was largely influenced by the EU's own Common Commercial Policy. Internal and external policies are clearly linked and the European Union sometimes simply needs to influence international legal developments to reach its internal

\footnotetext{
${ }^{32}$ Respectively 18 April 1961, entry into force on 24 April 1964, United Nations, Treaty Series, vol. 500, p. 95; and 24 April 1963, entry into force on 19 March 1967, United Nations, Treaty Series, vo1. 596, p. 261.

${ }^{33}$ See more extensively: RA Wessel, 'Immunities of the European Union' (2014) 11 International Organizations Law Review 395-418; as well as RA Wessel and B Van Vooren, 'The EEAS' Diplomatic Dreams and the Reality of International and European Law' (2013) 20 Journal of European Public Policy 1350-1367.

${ }^{34}$ See for instance the contributions to Van Vooren et al. (n 18).

${ }^{35}$ [...] Cf. also B de Witte, 'International Law as a Tool for the European Union' (2009) 5 EUConst $265-283$ at 278.

${ }^{36}$ Marrakesh Agreement establishing the World Trade Organization (with final act, annexes and protocol). Concluded at Marrakesh on 15 April 1994, 1867 U.N.T.S. 154, 33 I.L.M. 1144 (1994).
} 
objectives. ${ }^{37}$ Indeed, in these cases, the EU sees itself as a 'rule generator', ${ }^{38}$ or a 'norm entrepreneur'. 39

One particular issue concerns the question of whether the EU can bind non-EU members; the question of the so-called 'extraterritorial effects'. Obviously, it can set the rules for everyone involved in dealings with the EU or its Member States in areas where it has a competence. However, the question is to what extent it can set rules that go beyond this scope. The 'external effects of EU law' is slowly developing as a sub-discipline of EU external relations law that studies these effects. Thus, questions have been raised to which extent, for instance, American passengers may invoke EU Regulation 261/2004 - on claims in case of delayed, cancelled or denied boarding on certain flights - in US courts. A fact is that the Regulation is not explicitly restricted to EU Member States. ${ }^{40}$ Similar 'external effects' have been found in relation to climate norms, market access, data protection, the law of the sea, or financial aid. ${ }^{41}$

\subsection{Unilateral acts}

Apart from international agreements, unilateral acts issued by the EU may form a source of international law. In fact, some of the examples referred to above in relation to 'external effects' may in fact be unilateral acts. They concern Regulations with clear external effects, which on the basis of international law bind the Union vis-à-vis third states that may claim to have in good faith relied on EU law. This type of internal acts with external effects can be found both in relation to internal market issues, ${ }^{42}$ as well as on for instance foreign policy (see

\footnotetext{
${ }^{37}$ See for instance. M Cremona, 'Expanding the Internal Market: An External Regulatory Policy for the EU?', in Van Vooren et al. (n 18)

${ }^{38}$ M Cremona, 'The Union as a Global Actor: Roles, Models, and Identity', CMLR, 2004, pp. 553, at 557.

${ }^{39}$ E Herlin-Karnell, 'EU Values and the Shaping of the International Legal Context', in D Kochenov and F Amtenbrink (eds.), The European Union's Shaping of the International Legal Order (Cambridge University Press 2013) 89-107 at 103.

${ }^{40}$ References to this idea may for instance be found in I Koning, 'The Influence of European Law on Dutch Private Law', in AS Hartkamp, CH Sieburgh, LAD Keus, JS Kortmann, MH Wissink (eds.), De Invloed van het Europese recht op het Nederlandse Privaatrecht (Kluwer, 2014) 861-891.

${ }^{41}$ See for instance the research project on External Effects of EU Law of Utrecht University in cooperation with the Hague based Centre for EU External Relations (CLEER): http://renforce.rebo.uu.nl/en/bouwsteenprojecten/externe-effecten-van-eurecht/; B Kleizen, 'Externalizing EU Law, Policy and Values - Europe's Global Identity, Mechanisms of Rule Transfer and Case Studies on Illegal Logging and Bosnia and Herzegovina', 2015, available on SSRN, http://ssrn.com/abstract=2706564.

${ }^{42}$ An example being the EU's Generalised Scheme of Preferences" (GSP), which allows for developing country exporters to pay less or no duties on their exports to the EU. This gives them vital access to EU markets and contributes to their economic growth. See Regulation (EU) No 978/2012 of the European Parliament and of the Council of 25
} 
below $^{43}$ ). Indeed, once the Union has succeeded in formulating a policy, this may result in the creation of expectations on the side of the third party. It is generally held that apart from the Member States and the institutions, the third States involved must be able to rely on the official decisions of an organisation. ${ }^{44}$ Thus, the legal effects of EU Decisions would, in that sense, reach beyond the internal system of the EU legal order.

It is widely recognised in international law that unilateral acts may impose restrictions on the speaker's discretion regarding the topic of the act, due to the fact that other States must be able to rely, in good faith, upon statements made by any other State. ${ }^{45}$ According to Brownlie, for instance, it is accepted in international legal doctrine that 'a state may evidence a clear intention to accept obligations vis-à-vis certain other states by a public declaration which is not an offer or otherwise dependent on reciprocal undertakings from the states concerned'. ${ }^{46}$ But apart from cases in which a State or an international organisation intended to accept obligations vis-à-vis other States, it may nevertheless be obliged to act in line with its own statements on the basis of the principle of good faith. Thus, where good faith can be regarded to be at the basis of the pacta sunt servanda rule, when bi- or multilateral agreements are concerned, it may equally be a source for obligations not based on an agreement but on an international unilateral act. In Zoller's words: 'In fact, good faith can intervene either to determine a subjective interpretation which is closely bound to the will of the Parties, or to bring into being an objective interpretation which is independent of their will'. ${ }^{47}$ In the latter case, the notion of good faith usually

October 2012 applying a scheme of generalised tariff preferences and repealing Council Regulation (EC) No 732/2008.

${ }^{43}$ As well as RA Wessel, The European Union's Foreign and Security Policy: A Legal Insititutional Perspective (Kluwer Law International 2009), Chapter V.

${ }^{44} \mathrm{Cf}$. J Klabbers, The Concept of Treaty in International Law (Kluwer Law International 1996) at 94.

${ }^{45}$ See in particular the classic work of E Suy, Les Actes Juridiques Unilatéraux en Droit International Public (Pichon \& Durant-Auzias 1962); as well as K Zemanek, 'Unilateral Acts Revisited', in K Wellens (ed.), International Law: Theory and Practice (Kluwer Law International 1998) 209-221. With regard to good faith the International Court of Justice in the Nuclear Tests cases argued: "One of the basic principles governing the creation and performance of legal obligations, whatever their source, is the principle of good faith. Trust and confidence are inherent in international co-operation, in particular in an age when this co-operation in many fields is becoming increasingly essential. Just as the very rule of pacta sunt servanda in the law of treaties is based on good faith, so also is the binding character of an international obligation assumed by unilateral declarations and place confidence in them, and are entitled to require that the obligation thus created be respected" (para. 46); ICJ Reports 1974.

${ }^{46}$ I Brownlie, Principles of Public International Law (Clarendon Press 1990) at 637.

${ }^{47}$ E Zoller, La Bonne Foi en Droit International Public (Éditions A. Pedonne 1977) at XIX and $\S 215-219$. This book still serves as one of the most comprehensive studies on the concept of good faith in international law. Nevertheless, this approach of good faith adds to the complexity already apparent in the doctrine on unilateral acts. See for the 
finds a concrete application in the principle of estoppel, originating in 'the simple fact that the law will demand consistency in conduct where the results of inconsistency would be to prejudice another party' ${ }^{48}$

Criteria to justifiably make use of the principle of estoppel were for instance already listed by Bowett: (1) there must be a statement of fact which is clear and unambiguous; (2) this statement must be voluntary, unconditional, and authorised; and (3) there must be reliance in good faith upon the statement, either to the detriment of the party so relying on the statement or to the advantage of the party making the statement. ${ }^{49}$ In this respect, it is important to note that unilateral acts through the doctrines of good faith and estoppel - do not create valid legal norms; they concern law-application rather than law-making. In the words of the International Court of Justice, good faith alone cannot create obligations where none would otherwise exist. ${ }^{50}$ Nevertheless, the Court, in the (widely criticised ${ }^{51}$ ) Nuclear Tests judgement also took the stance that '[i]t is well recognized that

illogical use of both subjective and objective elements in the determination of the binding nature of a unilateral statement: M Kosekenniemi, From Apology to Utopia: The Structure of International Legal Argument (Laimiesliiton Kustannus 1989) at 303-311. While it goes beyond the purpose of the present paper to analyse the doctrine on unilateral acts in more detail, elements of Koskenniemi's criticism are acknowledged, in particular where the difficult establishment of subjective intent on the basis of objective arguments is concerned.

${ }^{48}$ A Nollkaemper, The Legal Regime for Transboundary Water Pollution: Between Discretaion and Constraint (Martinus Nijhoff Publishers 1993) at 214; IC MacGibbon, 'Estoppel in International Law' (1958)ELR, 468-513 at 468: the "requirement that a state ought to be consistent in its attitude to a given factual or legal situation". According to Zoller (n 47) at XXIV: "Estoppel does not sanction an absence of good faith, but protects the good faith of the victim".

${ }^{49}$ DW Bowett, 'Estoppel before International Tribunals and its Relation to Acquiescence' (1957) 33 BYIL 176-210 at 202. It is in that respect confusing that in the Nuclear Tests case (n 45; at 267, para. 43) the International Court of Justice seemed to point to the necessary presence of a subjective element: the state making the unilateral statement must have the intention to impose on itself an obligatory norm, not meant to be modified at random. Compare in that respect also R Higgins, Problems \& Process: International Law and How We Use it (Clarendon Press 1994) at 35: "Unilateral acts will be binding on the state making them only if they evidence an intention to be bound". The confusing element is to be found in the fact that wherever a state has the intention to unilaterally bind itself, there is no need to invoke the doctrine of estoppel. Estoppel only comes in when the intention is unclear, and when a third state nevertheless expected a certain behaviour.

${ }^{50}$ See Border and transborder armed action (Nicaragua v. Honduras), ICJ Reports 1988, at 105, para. 94. Also compare Higgins (n 49) at 35, who seems to mean the same, when she asserts that "unilateral acts may be the source of an obligation undertaken but not of the norm which thereby becomes opposable".

${ }^{51}$ See alsoAP Rubin, 'The International Legal Effects of Unilateral Declarations' (1977) 71 AJIL, 1-30 at 29. See on the Court's ambiguous approach to unilateral acts also Koskenniemi, op.cit. at 303-311. 
declarations made by way of unilateral acts, concerning legal or factual situations, may have the effect of creating legal obligations'. ${ }^{52}$

This considerably extends the scope of the external effect of EU action. Potentially, it not only includes a wide range of decisions taken in the framework of the Union's Foreign and Security Policy, but also the vast amount of 'Declarations' issued by the Union (or the High Representative for Foreign and Security Policy) on an almost daily basis. Obviously, the statements must have been phrased in a way to trigger legitimate expectations on the side of third states which are to be upheld by the Union. Hence, both the text and the question of legitimate expectations count for the possibility of international obligations to emerge.

Yet, EU law first and foremost purports to be binding on the Member States of the Union; its objective is to establish a common policy among the Member States, rather than to address the particular third State that happens to be the subject of this policy. Thus, most of the time, we are not dealing with unilateral acts through which the Union intended to create for itself obligations vis-à-vis third States. And, whenever they do reflect international legal effects, they are often phrased as 'policy objectives' rather than as unambiguous promises to engage in concrete actions. Failing an intention on the part of the Union to create a legal obligation, EU policies may nevertheless become manifest in the international legal order through the application of the doctrine of estoppel. It is necessary then to confront the statements with the criteria to justifiably invoking this doctrine. Keeping in mind the sometimes rather vague wording used in for instance CFSP Decisions, the first two criteria mentioned by Bowett (i.e. a statement of fact which is clear and unambiguous as well as voluntary, unconditional, and authorised) are not by definition fulfilled. The third criterion (i.e. reliance in good faith upon the statement, either to the detriment of the party so relying on the statement or to the advantage of the party making the statement) may even be more difficult to meet. Regarding the determination of the exact statement of the Union it is helpful, however, that in practice the Union cannot, later, deny its initial position vis-à-vis the third States concerned, since, after all, most EU legislation and policies are made in public and are usually even published in the Official Journal.

Finally, very concrete interpretations of international law may be laid down in amicus curiae briefs, which may be used by the European Union to share its views on certain legal issues with foreign (national as well as international) courts.

${ }^{52}$ Nuclear Tests case, para. 43 (n 45). 


\subsection{Customary law}

Again, the way in which international customary law may form part of the EU legal order has been extensively researched over the years - not least in Konstadinides' contribution to this Special Issue. ${ }^{53}$ At the same time, we have studied special cases of customary law. ${ }^{54}$ Examples of EU law as a source of customary international law, on the other hand, are hard to find. This is not to say that we should exclude it for the future. In its contribution to the UN Sixth Committee, the EU was quite explicit about its potential contribution to international customary law:

implicit in this recognition of the EU as a treaty partner is the view that international community considers an organization such as the EU as also capable of contributing to the development of international law in other contexts, including the formation of customary international law. In this context, too, the Union's action is based on the responsibilities that the Member States have trusted on it. Indeed, the EU's founding treaties provide that the Union 'shall contribute to the strict observance and the development of international law'. 55

In fact, in relation to the internal division of competences, the Union argued that 'in areas where, according to the rules of the EU Treaties, only the Union can act it is the practice of the Union that should be taken into account with regard to the formation of customary international law alongside the implementation by the Member States of the EU legislation'. ${ }^{56}$

While the peculiar, or at least specific, nature of the EU may form an annoyance for non-EU States, it can not be denied indeed that, for instance, the ways in which the Union - mostly as a non-member - participates in international organizations may be said to have resulted in the custom that (certain) international organizations may operate alongside States (see also below). More in general, '[a] generalized understanding has emerged that whenever an EU Member State comes to the international-negotiation table, the European-law

\footnotetext{
${ }^{53}$ See (also for further references) for instance A Gianelli, 'Customary International Law in the European Union', in Cannizzaro et al. (n 2) 93-110.

${ }^{54}$ See A D'Amato 'The Concept of Special Custom in International Law', 63 American Journal of International Law, 1969, 211-223.

${ }^{55}$ Statement on behalf of the European Union by Eglantine Cujo, Legal Adviser, Delegation of the European Union to the United Nations, at the Sixth Committee on Agenda item 78 on Identification of customary international law, 3 November 2014. See however the hesitation by Special Rapporteur Michael Wood in his Third Report on Identification of Customary International Law, International Law Commission, Sixtyseventh session Geneva, 4 May-5 June and 6 July-7 August 2015, 27 March 2015, UN Doc. A/CN.4/682. Credits are due to Odermatt (n 7) at 293.

${ }^{56}$ Ibid (EU Statement).
} 
implications will be part of the agenda. Accordingly, third parties adjust to this state of affairs, and the question today is whether this EU-friendly treatment has reached the status of an international custom'. ${ }^{57}$ Similarly, the acceptance of the Union Delegations abroad as corollaries of national embassies and the roles the Heads of Delegations are allowed to play among national Ambassadors, already seem to have led to forms of unwritten law. ${ }^{58}$

Apart from these examples, which basically relate to a possible 'State-like' acceptance of the legal position of the EU in certain situations, the contribution of the EU to customary law may be related to certain interpretations, in particular in the area of treaty law. While the EU has never ratified the 1986 Vienna Convention on the Law of Treaties between States and International Organizations or between International Organizations, it is generally held that the most important aspects of this Convention are part of customary law; and, indeed, are applied by the Union all the same. ${ }^{59}$ In general, the European Union follows international treaty law and its Court has frequently interpreted EU law in the light of the provisions of the Conventions (interestingly enough, mostly the 1969 Convention on Treaties between States). ${ }^{60}$ Possible contributions to the development of international customary law could be found in the fact that - as international agreements concluded by the Union form an integral part of EU law and bind both the institutions and the Member States alike (Article 216(2) TFEU) - the notion of 'domestic law' is presented in a novel way. ${ }^{61}$ In the legal set-up of the European Union, international agreements (treaties) concluded by the EU thus also have effects in 28 sovereign States. While one may rightfully argue that these rules find their basis in internal EU law, one of the key notions of international treaty law - pacta tertiis nec nocent nec prosunt $-{ }^{62}$ seems to be put into perspective.

\footnotetext{
${ }^{57}$ M Ličková, 'European Exceptionalism in International Law' (2008) 19 EJIL 463-490 at 464.

${ }^{58}$ See P Kerres and RA Wessel, 'Apples and Oranges? Comparing the European Union Delegations to National Embassies' (2015) CLEER Papers; as well as J Wouters and S Duquet, 'The EU and International Diplomatic Law: New Horizons?' (2012) 7 Hague Journal of Diplomacy 31-49; and J Wouters and S Duquet, 'Unus inter plures? The EEAS, the Vienna Convention and International Diplomatic Practice', in J. Bátora and D. Spence (eds.), The European External Action Service: European Diplomacy PostWestphalia (Palgrave MacMillan 2015).

${ }^{59}$ Gianelli (n 53) See in general also C Brölmann, The Institutional Veil in Public International Law: International Organisations and the Law of Treaties (Hart Publishing 2007).

${ }^{60}$ Hoffmeister (n 12) at 57-64; as well as in general Cannizzaro et al. (n 2). For analysis of the approach of the CJEU to the interpretation of internal EU norms, generally disregarding (or at least adapting) VCLT rules, see Gunnar Beck's contribution to this Special Issue.

${ }^{61}$ Cf. also J Odermatt, 'The Court of Justice of the European Union: International or Domestic Court?' (2014), Cambridge Journal of International and Comparative Law, 2014, p. 696.

${ }^{62}$ Cf. Articles 34-36 of the Vienna Convention on the Law of Treaties.
} 
Arguably, in the longer run, EU interpretations of international legal rules may have an effect on the development of customary law. Thus, the question could be raised whether, for instance, the interpretation of the circumstances in which the right to collective defence ${ }^{63}$ can be used was influenced by the broad interpretation of this right by the French government (supported by other EU Member States) after the terrorist attacks in Paris in 2015. It has been suggested that 'France's political leadership envisages assistance in broader policy terms than simply security and defence'. ${ }^{64}$ Indeed, Article 42(7) TEU contains the 'mutual assistance clause' calling on EU Member States to provide 'aid and assistance by all the means in their power' in case a fellow Member State is the 'victim of armed aggression on its territory'. Indeed, somehow the choice was made to invoke this particular provision in relation to a terrorist attack, rather than Article 222 TFEU, which explicitly refers to a situation like this: 'The Union and its Member States shall act jointly in a spirit of solidarity if a Member State is the object of a terrorist attack ...'. Admittedly the effect of this perhaps incidental interpretation on international law is limited, in particular since no practical follow-up could be witnessed since.

Another example is formed by the EU's role in in shaping the law on standing and jurisdiction in the context of international dispute settlement. A recent study concludes that two examples are particularly telling. First, "[t[he EU has contributed to the elaboration of practice concerning countermeasures in response to breaches of international obligations, including practice concerning third party countermeasures for violations of erga omnes (partes) obligations, such as the prohibition of the use of force and grave violations of human rights. [...] Second, the EU has contributed to significant treaty practice that confers jurisdiction to international judicial and quasi-judicial fora to entertain claims concerning the responsibility (or non-compliance) of states and international organisations either brought by states or brought by IOs against states." ${ }^{, 95}$

Other traces of, at least, a 'European' influence on international norms may be found in the effects of the case law of the European Court of Human Rights. A case in point may be the tension between the international rules on the immunity

\footnotetext{
${ }^{63}$ As codified in Article 51 of the UN Charter.

${ }^{64} \mathrm{C}$ Hillion and S Blockmans, 'Europe's self-defence: Tous pour un et un pour tous?', CEPS Commentary, 20 November 2015. See also E Cimiotta, 'Le implicazioni del primo ricorso alla c.d. 'clausola di mutua assistenza' del Trattato sull'Unione europea', European Papers/European Forum, 16 April 2016, 1-13 (http://www.europeanpapers.eu/en/europeanforum/le-implicazioni-del-primo-ricorsoclausola-di-mutua-assistenza-tue).

${ }^{65}$ D Azari, 'The European Union's Contribution to Shaping the Law on Standing and Jurisdiction in the Context of International Dispute Settlement', in M Cremona, A Thies and RA Wessel (eds.), The European Union and International Dispute Settlement (Hart Publishing 2016, forthcoming).
} 
of international organizations and the right to fair trial. The latter is laid down in Article 6 of the European Convention on Human Rights and the interpretation of the Court is that this right entails that international organizations are to cater for a system of 'equivalent protection' compared to that of states. ${ }^{66}$ While international organizations are, presumably, not bound by the European Convention as such, European Member States of those organizations are, ${ }^{67}$ and domestic courts in these States increasingly use the criteria formulated by the Human Rights Court to question the immunity of international organizations with headquarters on their territory. ${ }^{68}$

\subsection{Influencing law-making by international institutions}

One way to contribute to international law-making is through participation in international organizations. ${ }^{69}$ Again, in most legal studies this question is neglected. While the influence of international organizations on the EU has occasionally been subject to legal scrutiny, ${ }^{70}$ the ways in which the EU may influence rule-making by international organizations is largely left to political scientists. $^{71}$

\footnotetext{
${ }^{66}$ See on the relevant case law for instance A Reinisch and UA Weber, 'In the Shadow of Waite and Kennedy: The Jurisdictional Immunity of International Organizations, The Individual's Right of Access to the Courts and Administrative Tribunals as Alternative Means of Dispute Settlement (2004) 1 International Organizations Law Review 59-110. See on a recent view by a number of European lawyers: Brief of European Law Scholars and Practitioners as Amici Curiae in Support of Plaintiffs-Appellants, Case Delama Georges et al. v .United Nations et al, United States Court of Appeals, No. 15-455, 2015 (http://www.ijdh.org/wp-content/uploads/2015/06/EuroLaw-Amicus-Brief.pdf).

${ }^{67}$ Ibid.

${ }^{68}$ As shown in a recent study of the Dutch Advisory Committee on Issues of Public International Law (CAVV) on the Responsibility of International Organizations, December 2015 (English translation forthcoming on http://www.cavvadvies.nl/3bz/home.html).

${ }^{69}$ Cf. S Blavoukos and D Bourantonis (eds.), The EU Presence in International Organizations (Routledge 2010).

${ }^{70}$ See RA Wessel and S Blockmans (eds.), Between Autonomy and Dependence: The EU Legal Order under the Influence of International Organisations (TMC Asser Press 2013).

${ }^{71}$ See for instance: S Oberthür, KE Jørgensen and J Shahin (eds.), The Performance of the EU in International institutions (Routledge 2013); KE Jørgensen (ed.), The European Union and International Organizations (Taylor \& Francis 2009); E Drieskens, 'Towards a Systematic Analysis of the EU As An Actor in the UN System' (2010) 1 Journal of International Organizations Studies 105-108; and S Oberthür and L Groen, 'The Effectiveness Dimension of the EU's Performance in International Institutions: Toward a More Comprehensive Assessment Framework' (2015) 53 Journal of Common Market Studies 1319-1335; as well as Blavoukos and Bourantonis (n 69). See for a more legal approach recently, however also C Kaddous (ed.), The European Union in International Organisations and Global Governance (Hart Publishing 2015); and earlier also Hoffmeister (n 12); and RA Wessel, 'The Legal Framework for the Participation of the European Union in International Institutions' (2011) 33 Journal of European Integration $621-635$.
} 
Apart from its participation in a number of actual international organizations, the institutionalization of the role of the EU in the world is reflected in its position in international regimes in various policy fields. The position of the EU in international institutions is part and parcel of EU external relations law and it is at these fora that a structural role of the EU in global governance becomes most visible. Moreover, it is this role that has become more interesting now that it becomes clear that many EU (and national) rules find their origin in decisionmaking processes in other international organizations, exemplified by rules on trade, the environment, food safety or technical standards. ${ }^{72}$

Over the years the EU has obtained a formal position in some international institutions, either as a full member or as an observer. It is generally held that the participation in a formal international organization relates to the participation in its organs, i.e. the right to attend the meetings, being elected for functions in the organ, and exercising voting and speaking rights. In that sense, the term 'position' is related to a formal influence on the output of the international organization (UN, ICAO, etc.): decisions (often recommendations, but in some occasions binding decisions) and conventions (i.e. international agreements prepared and adopted by an organ of an international organization). In addition, the EU participates in less formal international institutions (or regimes) such as the G-20, for example. The Treaties herald an increase of the engagement of the EU in other international institutions, including the future membership of additional international organizations, such as the Council of Europe as a result of the EU's foreseen accession to the European Convention on Human Rights (Article 6 TEU). ${ }^{73}$

The question of how effective the EU has been in influencing the outcome of law and policy-making processes at international institutions is again one that has primarily been on the table of non-lawyers. Overall - and despite major internal turf-battles - the view is that the EU's influence is quite substantive, ${ }^{74}$ and that it largely practices what it preaches in terms of the promotion of values. ${ }^{75}$

\footnotetext{
${ }^{72}$ A Føllesdal, RA Wessel and J Wouters (eds.), Multilevel Regulation and the EU: The Interplay between Global, European and National Normative Processes (Martinus Nijhoff Publishers 2008).

${ }^{73}$ Yet, that this is also a source of new conflicts between the EU legal order and international obligations is reflected in Opinion 2/13 of the Court on the accession of the EU to the European Convention on Human Rights. See, more extensively, A Łazowski and RA Wessel, 'When Caveats turn into Locks: Opinion 2/13 on Accession of the European Union to the ECHR' (2015) 16 German Law Journal 179-212. See also Eileen Denza's contribution to this Special Issue.

${ }^{74}$ For a general overview of different opinions see C Hill and M Smith, 'Acting for Europe: Reassessing the European Union's Place in International Relations', in C Hill and M Smith (eds.), International Relations and the European Union (OUP 2011; $2^{\text {nd }} \mathrm{ed}$ ). ${ }^{75}$ Cf. S Lucarelli and I Manners (eds.), Values and Principles in European Foreign Policy (Routledge 2006). See for legal analyses of this matter: M Cremona, 'Values in EU Foreign Policy', in M Evans and P Koutrakos (eds.), Beyond the Established Legal
} 
One obvious problem is related to the fact that the EU's (exclusive) competences are not always met with its ability to join an international institution. International organizations are traditionally made for States and the majority of them does not allow for the EU to become a member. In those situations the EU has to rely on it Member States, which will occasionally lack competences of their own and act as 'agents' of the European Union. ${ }^{76}$ In relation to the topic of the present contribution one may of course wonder whether in those cases it is EU law that is used to influence the international rules. However, given the fact that EU Member States merely act in the absence of the EU as a formal member and in fact represent the EU, on certain issues, it seems fair to conclude that the contribution to international law-making is indeed made by the EU as such. ${ }^{77}$ A clear example is formed by the EU's influence on international maritime rules. Again, in the formal absence of the EU itself, it is represented by its Member States in the International Maritime Organization (IMO), but one may argue that in this case the Member States merely act as agents and that it is indeed EU law that they bring to the international level. As one of the most important global players in the area, the EU has a large influence on, for instance, (the interpretation of) the rules on vessel-source pollution. The package of EU law and regulation in this area is quite extensive and cannot be ignored by anyone sailing the European waters. ${ }^{78} \mathrm{At}$ the same time, the question has been raised whether the regional or unilateral nature of these rules does not in fact undermine the authority of general international law. ${ }^{79}$

\subsection{Strengthening international law through judicial referencing and interpretation}

While references by the European Court of Justice to international law standards and judgments of the International Court of Justice (ICJ) may by themselves contribute to law-making, they may in particular confirm and strengthen certain international rules. ${ }^{80}$ As Kassoti and Louwerse found: 'A survey of the ever-

Orders: Policy Interconnectedness between the EU and the Rest of the World (Hart Publishing 2011); and Herlin-Karnell (n 39 )

${ }^{76}$ A clear example if formed by the International Labour Organization (ILO); see on this also Opinion 2/91, 19 March 1993; ECLI:EU:C:1993:106.

${ }^{77}$ An interesting example is formed by the 1999 Hushkits case before the ICAO Council, initiated by the United States against the collectivity of the EU Member States, but on a topic that fell into the Union's competence. As the EU itself was/is not a member of ICAO, its position was defended by the Member States, who in turn authorized the Director-General of the Commission's Legal Service to act as their agent 'in his personal capacity'. See Hoffmeister (n 12) at 50.

${ }_{78}^{78}$ See http://ec.europa.eu/maritimeaffairs/index_en.htm.

${ }^{79}$ L Nengye and F Maes, 'The European Union and the International Maritime Organization: EU's External Influence on the Prevention of Vessel-Source Pollution' (2010) 41 Journal of Maritime Law \& Commerce 581-594 at 582.

${ }^{80} \mathrm{~J}$ Crawford, Brownlie's Principles of Public International Law (Cambridge University 
burgeoning CJEU jurisprudence reveals that the EU courts, when faced with questions of international law, show a high degree of deference to the case-law of the ICJ and use it as an authoritative interpretation of international norms that are of relevance to their work. This is especially the case when they are faced with questions of customary international law - chiefly relating to international law of the sea and to international treaty law' ${ }^{81}$ And, 'recent practice shows that the EU Courts are making knowledgeable references to the case-law of the ICJ in order to settle a wider gamut of international law questions. These include: the question of the customary law status of the 1963 Vienna Convention on Consular relations; the question of the primacy of the UN Charter and of SC resolutions over other international agreements; questions of jus cogens; as well as questions relating to the scope and content of the principle of non-intervention' ${ }^{82}$

Yet, again it remains unclear to which extent these references by the CJEU have contributed to international law-making. Where the CJEU is believed to have had some influence is through its interpretation of international treaty law. As Odermatt argued, '[b]y applying the VCLT, the CJEU can be seen as contributing to the "strict observance and the development of international law". Like any domestic Court, however, the CJEU may employ international treaty law in a way that deviates from established practice in international law...This means the CJEU will sometimes contribute to international law by deciding upon the customary international law status of the VCLT rules'. ${ }^{83}$ Odermatt's study also points to the fact that the Court often interprets treaty law in a somewhat 'selfish' way and its application is influenced by its approach to the interpretation of EU law. ${ }^{84}$ This may even lead to a misuse of international law and to further fragmentation. ${ }^{85}$

Press $2012,8^{\text {th }}$ ed.) at 194: "Clearly decisions of judicial organs, such as the International Court of Justice and the Court of Justice of the European Union, contribute to the development of the law of treaties including principles of interpretation as well as general international law. The specialized function of such bodies may naturally limit their contribution to the latter."

${ }^{81}$ E Kassoti and L Louwerse, 'Like Ships in The Night? The CJEU and the ICJ at the Interface', paper presented at the 1st Jean Monnet workshop on the Dialogue Between Judges: The Court of Justice of the European Union and Other International Courts, Geneva, 23-26 September 2015.

${ }^{82}$ Ibid. at 19.

${ }^{83}$ Odermatt (n 7) at 127.

${ }^{84}$ Ibid. at 145. Cf. also B De Witte, 'A Selfish Court? The Court of Justice and the Design of International Dispute Settlement Beyond the European Union', in M Cremona and A Thies (eds.), The European Court of Justice and External Relations Law: Constitutional Challenges (Hart Publishing 2014) 33-46. Cf. On the CJEU's approach to the interpretation of internal EU law, see Gunnar Beck's contribution to this Special Issue.

${ }^{85}$ Ibid. 
Yet, it may be also argued that by relying on ICJ interpretations of international law and by confirming the status of the rules, the EU in fact contributes to the coherence of the international legal system. Even more relevant for the purpose of the present paper would be cases in which the ICJ would refer to EU law and use this as a source to interpret (or make) international law. However, as found by Penelope Nevill in one of the rare contributions on this topic: 'There are no references to the decisions of the EU courts in judgments of the ICJ, the InterAmerican Court of Human Rights, the Iran-US Claims Tribunal or International Tribunal for the Law of the Sea (hereinafter 'ITLOS') awards. Only a very indirect reference to EU law may perhaps be found in the ICJ judgment on the Dispute regarding Navigational and Related Rights (Costa Rica v. Nicaragua), where the ECJ's view on commercial policy as presented in its Opinion 1/76 was accepted by the ICJ. ${ }^{86}$ By contrast, the ICJ, Iran-US Claims Tribunal and the Inter-American Court cite judgments of the European Court of Human Rights and domestic courts'. ${ }^{87}$ Nevill adds that 'World Trade Organization...panel and Appellate Body reports refer to judgments of the European Court of Justice...but references are for the most part made in the context of an analysis of compliance by the EU and its member states with their WTO obligations, not as a subsidiary source of international law' ${ }^{88}$ Indeed, EU law is generally perceived as different or special by international tribunals, as for instance became clear in a WTO Panel decision when China relied on a judgment of the CJEU: $:{ }^{89}$ 'the fact that it may be legally appropriate for the [CJEU] not to apply EC rules on the free movement of goods to an import transaction involving hard-copy cinematographic film does not mean that it would be legally appropriate for a WTO panel not to apply China's trading rights commitments to an analogous import transaction'. ${ }^{90}$

Nevill's study highlights that other international tribunals occasionally refer to CJEU case law, but that this case law hardly affects the outcome of a case. Thus, for instance, 'there are only a handful of cases where the ECJ judgment has been invoked by the [European Court of Human Rights] in support of a particular interpretation or application of a Convention right'. ${ }^{91}$ Even more scarce are references to EU law by the UN human rights bodies. On the other hand, in

\footnotetext{
${ }^{86}$ Judgment of 2009, par. http://www.icj-cij.org/docket/files/133/15321.pdf. Credits are due to Prof. Enzo Cannizzaro for drawing my attention to this case.

${ }^{87}$ Nevill (n 7) 281-295.

${ }^{88}$ Ibid, at 283.

${ }^{89}$ In casu Case C-17/92 Federación de Distribuidores Cinematográficos v. Estado Español and Unión de Productores de Cine y Televisión, ECLI:EU:C:1993:172.

${ }^{90}$ China - Measures Affecting Trading Rights and Distribution Services for Certain Publications and Audiovisual Entertainment Products (2009), Panel Decision of 12 August 2009. See more extensively Nevill (n 7) at 283.

${ }^{91}$ Nevill (n 7) at 284.
} 
investor-State disputes, EU Court judgments (as well as other EU law) do seem to play a somewhat larger role. ${ }^{92}$

In many cases, the EU, as reflected in the CJEU's case law, presents itself as a closed entity, zealous to maintain its autonomy. ${ }^{93}$ In a way, the EU Court itself has often positioned the EU in international organizations and as a party to multilateral conventions as a State-like actor. As argued by Nevill, 'the EU, via the ECJ, was, like any other state, controlling the conferral of standing on individuals to raise a breach of international law "domestically". ${ }^{94}$ Most ironically perhaps is the conclusion that " $[\mathrm{t}]$ he primary contribution of the EU to the development of WTO law has been as an actor alongside states: it generates much valuable Panel and Appellate Body jurisprudence by being sued and initiating proceedings ${ }^{95}$

\subsection{Other ways of influencing international law}

While the above-mentioned examples are the most clear expressions of the EU's possible contribution to international law-making, the Union's role in 'shaping the international legal order' ${ }^{96}$ is much more extensive. Conceptions of 'normative power Europe' have in particular been developed in International Relations Theory and EU Studies, ${ }^{97}$ which aim to draw attention to 'the EU's "promotion of norms in a normative way" - i.e. the promotion of multilateralism and of values such as respect for international law, human rights and democracy, through noncoercive means'. ${ }^{98}$ As recently held by Klabbers, 'by adopting positions both internally and externally, [the EU] contributes quite a bit to the development of international law on a number of substantive topics, for better or for worse, with topics including such things as international terrorism, the recognition of states, or the responsibility of international organizations under international law; and it plays an important role within the United Nations and other international organizations'. ${ }^{99}$ Indeed, extensive application as well as interpretation of international law is part of the day-to-day practice of the EU and may relate to territorial issues (including the right to self-determination), questions on jurisdiction (related inter alia to the reach of the Union's own jurisdiction or the extraterritorial jurisdiction of third states), dispute settlement ${ }^{100}$ or the enforcement of international law (for instance, through the establishment of

\footnotetext{
${ }^{92}$ Ibid.

${ }^{93}$ See recently, Cremona, Thies and Wessel (n 65)

${ }^{94}$ Nevill (n 7) at 289.

${ }^{95} \mathrm{Ibid}$.

${ }^{96} \mathrm{Cf}$. Kochenov and Amtenbrink (n 39)

${ }^{97}$ See references above (n 11).

${ }^{98}$ G de Búrca, 'EU External Relations: The Governance Mode of Foreign Policy', in Van Vooren, Blockmans and Wouters (n 18) 39-58 at 39-40.

${ }^{99}$ Klabbers, 'Straddling the Fence' (n 23) at 53-54. Cf. also Hoffmeister (n 11)

${ }^{100}$ Cremona, Thies and Wessel (n 65)
} 
sanctions regimes). ${ }^{101}$

Debating and applying international law does, however, not automatically contribute to law-making. Yet, on some occasions, the EU adds a normative aspect to its application and interpretation. ${ }^{102}$ The question then is to which extent the promotion of norms can lead to the development of international law. In that respect, it is well-known that EU views may function as a reference point in many areas. On the basis of their cooperation with the EU, third States may even (be forced to) adopt elements of EU law in their domestic legal orders. The more close the relationship with the EU is (candidate countries, associated countries, countries participating in the European Neighbourhood Policy, countries that are dependent on the EU for parts of their development, etc.), the more frequent this will be the case. ${ }^{103}$

In a more general sense, the International Law Commission (ILC) may form a venue for EU influence on international law-making. However, this influence should not be overestimated. For instance, while the EU had some influence on the ILC discussions on state responsibility, in particular in relation to third party reprisals, in the end, this had no effect on what the ILC believed to be a codification of customary law. ${ }^{104}$ A similar influence by the EU was related to the ILC debate on the responsibility of international organizations; ${ }^{105}$ again, however, not with the result that the EU succeeded in getting its special position accepted. ${ }^{106}$ In fact, as found by Nevill, the commentaries to the ILC's 2011

${ }^{101}$ See for an elaborate overview Hoffmeister (n 12).

${ }^{102}$ On this particular issue, regarding the EU's application and interpretation of the 1951 Geneva Convention on the Status of Refugees and its 'export' to other parts of the globe, see H Lambert, J McAdam and M Fullerton (eds), The Global Reach of European Refugee Law (CUP, 2013).

${ }^{103}$ Again, an example drawn from the asylum policy terrain and tracing this 'enhanced influence' (or imposition of EU standards), see R Byrne, G Noll and J Vedsted-Hansen (eds), New Asylum Countries? Migration Control and Refugee Protection in an Enlarged European Union (Brill, 2003).

${ }^{104}$ Hoffmeister (n 12) at 95.

${ }^{105}$ See for instance PJ Kuijper and E Paasivirta, 'Further Exploring International Responsibility: The European Community and the ILC's Project on Responsibility of International Organizations' (2004) 1 International Organizations Law Review 111; F Hoffmeister, 'Litigating against the European Union and Its Member States - Who Responds under the ILC's Draft Articles on International Responsibility of International Organizations?' (2010) 21 EJIL 723; J-M Cortés Martín, 'European Exceptionalism in International Law? The European Union and the System of International Responsibility' in M Ragazzi (ed.), The Responsibility of International Organizations: Essays in Memory of Sir Ian Brownlie (Martinus Nijhoff 2013) 189; Jd'Aspremont, 'A European Law of International Responsibility? The Articles on the Responsibility of International Organizations and the European Union' in V Kosta, N Skoutaris, V Tzevelekos (eds.), The EU Accession to the ECHR (Hart Publishing 2014) 75.

${ }^{106}$ See S McArdle and PJ Cardwell, 'EU External Representation and the International Law Commission: An Increasingly Significant International Role for the European Union?', in S Blockmans and RA Wessel (eds.), Principles and Practices of EU External 
Articles on the Responsibility of International Organizations (ARIO) 'make only ten references to EU practice in 104 pages and note in 2 others that certain statements made by the EU on a question of responsibility are not clear enough for the ILC to use as an example of practice on the point in question. The ILC cites EU sources to support articles intended for general application to all international organisations, but also acknowledges the EU as a special case that may fall outside general provisions'. ${ }^{107}$ The 'specialness' of the EU - leading also to a complex application of the principle that 'responsibility should follow competence' 108 - seemed to stand in the way of a contribution to the development of more general norms of international law. ${ }^{109}$ Or, as summarised by Odermatt: 'Rather than outright rejection of the EU position, the [ILC's] Special Rapporteur sought to take into account the diversity of international organizations in other ways, such as the rules of the organization and the inclusion of a lex specialis rule. One can understand the reluctance of the ILC to include "EU-specific" language in draft articles that are intended to have a broad and universal coverage. The ILC resisted calls to attach greater importance to the diversity of international organizations, leaning towards rules capable of a universal application'. ${ }^{110}$

Another well-known example of possible EU effects on the interpretation of international law can be found in the recognition of States. After the end of the Cold War, the European Community's 'Guidelines on the Recognition of New States in Eastern Europe and in the Soviet Union', ${ }^{111}$ which laid down specific requirements for recognition with regard to the rule of law, democracy, and human rights, prescribed the criteria for the recognition of the new States in both the former Soviet Union and in the former Yugoslavia. While these guidelines certainly set the standard for recognition by the EU Member States, they also played a decisive role in, for instance, the opinions of the Arbitration Commission of the International Conference on Yugoslavia and may even have influenced

Representation (2012) CLEER Working Papers 83-101. In fact, the opposite has happened in relation to the anti-smuggling rules in the 2000 Palermo Protocol, and in the recent adoption by the UNSC of a Resolution authorising the suppression of smuggling routes across the Mediterranean (by use of force); or with regard to the most recent changes introduced to the ICAO Convention and its eventual incorporation of carrier sanctions (first supranationalised at EU level), after initial resistance in previous rounds of reform. This trail is documented in V Moreno-Lax, Accessing Asylum in Europe: Extraterritorial Border Controls and Refugee Rights under EU Law (OUP, forthcoming) ch 5 .

${ }^{107}$ Nevill (n 7) at 290.

108 See E Paasivirtaa, 'The Responsibility of Member States of International Organizations? A Special Case for the European Union' (2015) 12 International Organizations Law Review 448-467.

${ }^{109}$ Cf. also Ličková (n 57)

${ }^{110}$ Odermatt (n 7) at 290.

111 Adopted by the Member States in the framework of the European Political Cooperation on 16 December 1991. 
recognition policies by other States. ${ }^{112}$ But the question is to which extent they have really formed a source of international law. Like the so-called 'essential elements clauses' on human rights and democracy in international agreements, ${ }^{113}$ one may argue that these are contributions to international law only in the sense that they form part of contractual obligations between the parties to the agreements.

Apart from these 'substantive' examples, it is important to note that the EU may have an influence on international law through particular procedural demands. The complex internal division of competences has an explicit external dimension. This dimension is visible both in the participation of the EU in other international institutions and in the conclusion of international agreements. As the areas in which the EU is exclusively competent are few, ${ }^{114}$ in many instances non-EU States and other international organizations are confronted with both the EU and its Member States in a complex and often unclear situation of 'mixity', which, in turn, contributes to the somewhat fuzzy international legal status of the EU. ${ }^{115}$ Indeed, as one observer held: 'The EU may present itself as a legal or a political entity. In both these forms, it may exert a direct or an indirect influence on the treaty-making process. For example, as a legal entity, the EU is a party...to international agreements such as those on fisheries or on environmental protection. The EU's dual character presents considerable difficulties in comprehending the legal aspects of its nature and activities'. ${ }^{116}$ While one may argue that from the perspective of international (treaty) law this does not change things (after all, all are parties in their own right), practice reveals that mixity does have an effect on the way international law is used or interpreted. ${ }^{117}$ In many cases, third parties call for so-called 'Declarations of Competence' to clarify the respective competences and responsibilities of the EU and its Member States, ${ }^{118}$ while at the same time the EU and its Member States may request for

${ }^{112}$ See JA Frowein, 'The Contribution of the European Union to Public International Law', in A von Bogdandy, PC Mavroidis, and Y Mény (eds.), European Integration and international Co-ordination: Studies in transnational economic Law in Honour of ClausDieter Ehlermann (Kluwer Law International2002) 171-179.

${ }_{114}^{113}$ See for instance the 2000 Cotonou Agreement, OJ L 173, 26.6.2013, Article 9.

${ }^{114}$ B. Van Vooren and R.A. Wessel, EU External Relations Law: Text, Cases and Materials (CUP 2014) Chapter 4.

${ }^{115}$ For a view from the outside see more extensively: C Eckes and RA Wessel, 'The European Union from an International Perspective: Sovereignty, Statehood, and Special Treatment', in T Tridimas and R Schütze (eds.), The Oxford Principles of European Union Law - Volume 1: The European Union Legal Order (OUP 2016, forthcoming)

116 KS Ziegler, 'International Law and EU Law: Between Asymmetric Constitutionalisation and Fragmentation' in A Orakhelashvili (ed.), Research Handbook on the Theory of International Law (Edward Elgar 2011) 268, at 310.

${ }^{117}$ Cf. also Klabbers, 'Straddling the Fence' (n 23) at 54.

${ }^{118}$ On Declarations of competence see J Heliskoski, 'EU Declarations of Competence and International Responsibility', in Evans and Koutrakos (n 72) 189-212; A Delgado Casteleiro, 'EU Declarations of Competence to Multilateral Agreements: A Useful Reference Base?' (2012) 17 European Foreign Affairs Review 491. 
'disconnection clauses' to limit the effect of certain international rules in relation to intra-EU situations and so safeguard the Union's acquis. ${ }^{119}$ For these reasons, one could argue that the participation of the EU and its Member States in the international legal order has, at least, led to an adaptation of a number of international rules and practices in a procedural sense, due to the special nature of the EU. In Klabbers' words, 'it appeals to a sense of exceptionalism that is difficult to square with the sense that all states (including the EU's member states) operate on a basis of equality'. ${ }^{120}$

When related to the Union's exclusive competences, the fact that both the EU and its Member States are international legal actors has resulted in what may perhaps be seen as one of the major effects on international law: the limits imposed on EU Member States as sovereign international actors. While sovereignty and Statehood may be seen as cornerstones of the international legal order, EU membership has imposed serious limitations on the international role of the Member States and hence on international law itself. Case law has revealed that EU principles, such as the principle of sincere cooperation, ${ }^{121}$ may have the effect of side-lining EU Member States in their dealing with other States or international organizations. States have thus been deprived of some of their basic international rights, including the right to negotiate or conclude international agreements. Cases such as Mox Plant, PFOS or Green Network serve as clear examples, ${ }^{122}$ and new (currently pending) cases hint at further attempts of the Commission to side-line the Member States. ${ }^{123}$ The story does not only hold for new international

${ }^{119}$ Cf. J Klabbers, 'Safeguarding the Organizational Acquis: The EU's External Practice' (2007) 4 International Organizations Law Review 57. On disconnection clauses: M Cremona, 'Disconnection Clauses in EC Law and Practice' in C Hillion and P Koutrakos, Mixed Agreements Revisited - The EU and its Member States in the World (Hart Publishing 2010); and CP Economidès and AG Kolliopoulos, 'La clause de deconnexion en faveur du droit communautaire: une pratique critiquable' (2006) 110 Revue Générale de Droit International Public 273.

${ }^{120} \mathrm{~J}$ Klabbers, 'Re-Inventing the Law of Treaties: The Contribution of the EC Courts' (1999) 30 Netherlands Yearbook of International Law 5-74.

${ }^{121}$ Cf. E Neframi, 'The Duty of Loyalty: Rethinking its Scope Through its Application in the Field of EU External Relations' (2010) 47 Common Market Law Review 323, at 359; J Larik and A Delgado Casteleiro, 'The Duty to Remain Silent: Limitless Loyalty in EU External Relations' (2011) 17 European Law Review 524-541.

${ }^{122}$ Case C-459/03 Commission v. Ireland[2006] ECR I-4635, Case C-246/07 Commission v. Sweden [2010] ECR I-1885 and Case C-66/13 Green Network SpA v Autorità per l'energia elettrica e il gas, ECLI:EU:C:2014:156 respectively. G De Baere, “'O, Where is Faith? O, Where is Loyalty?" Some Thoughts on the Duty of Loyal Co-operation and the Union's External Environmental Competences in the Light of the PFOS Case' (2011) 17 European Law Review 405-419.

${ }^{123}$ Examples include Case C-626/15 Commission v Council (OJC 59, 15.2.2016, p. 5-6) regarding the submission, in the name of the EU and its Member States, of a reflection document on a future proposal to the Commission for the Conservation of Antarctic Marine Living Resources, and Opinion 3/15 (OJ C 311, 21.9.2015, p. 13-13) on whether the EU exclusive competence to conclude the Marrakesh Treaty to facilitate access to published works for persons who are blind, visually impaired, or otherwise print disabled. 
agreements, but also for already existing agreements. The need to renegotiate bilateral investments treaties (BITs), as a result of newly developed EU competences, testifies to the idea that EU law may force the international legal arena to accept its influence. ${ }^{124}$ Indeed, from the outset, it was clear that EU law would not sit well with exiting international agreements, resulting in the (Article 351 TFEU) duty to adjust international obligations to align them with the new EU starting points. ${ }^{125}$ While for EU Member States this may 'simply' result in conflicting legal obligations, it is well-known that ' $[\mathrm{t}]$ he density of the [EU] legal order, the political interdependence of current members, and the immediacy of EU enforcement mechanisms encourage the EU Member States to honour their EU duties first'. ${ }^{126}$

Indeed, as held by Koutrakos, 'the Union has assumed various roles on the international scene over the years, and exporting its norms and standards has been paramount among them. However, the prominence of the international role of the EU has had an impact on the Member States and the manner in which they exercise their powers as sovereign subjects of international law both in terms of their interactions with third countries and their participation in international organisations'. ${ }^{127}$ The question as to which extent all of this is also accepted within the international legal order will be addressed in the next section.

\section{Reception of EU Law by International Law}

From a more theoretical perspective, the question with which this section is concerned is to which extent the international legal order is, or should be, open to EU norms as a source for new (or adapted) international law. To start with the obvious: it is up to any legal order to decide on rules on the reception of norms originating outside of that order. There is, hence, no way in which EU norms can force themselves into the international legal order. This has also been recognised by the European Union itself: 'To preserve harmonious international relations, States and international organizations such as the European Union must respect the substantive and procedural limits imposed by international law on the authority of any individual State to apply its laws beyond its own territory'. ${ }^{28}$

\footnotetext{
${ }^{124}$ See also C Titi, 'International Investment Law and the European Union: Towards a New Generation of International Investment Agreements' (2015) 26 European Journal of International Law 639-662.

${ }^{125}$ J Klabbers, Treaty Conflict and the European Union (CUP2009).

${ }^{126}$ Ličková (n 57) at 469.

${ }^{127}$ P Koutrakos, 'In Search of a Voice' (n 5) at 212.

${ }^{128}$ Brief of the European Commission on behalf of the European Union as amicus curiae in support of neither party, Case Esther Kiobel, individually and on behalf of her late husband, dr. Barinem Kiobel, et al., v. Royal Dutch Petroleum co., et al., 2012, United States

Supreme

Court,
} 
The famous Kadi-saga before the Court of Justice of the European Union, ${ }^{129}$ revived the debate on the status of international law in the European Union. The question of whether the (largely) 'monist' nature of the EU legal order vis-à-vis international law would or could have its limits was raised in relation to the tension between international (in this case UN Security Council) obligations and the Union's own rules on the protection of fundamental rights. A side effect was that the international community realised that certain adaptations in the UN's system of legal protection were necessary in order to maintain the authority of the UNSC decisions. Thus, there was undoubtedly a link between the internal EU debates and the changes at the global level. Yet, it is equally clear that the modifications were merely inspired by the European debate; obviously, there was no automatic reception of EU (case) law in the law of the UN.

In a formal sense, the 'reception' of EU law in the international legal order will have to follow the sources doctrine. This in itself does not make it easier, as the sources of international law form a classic area of legal academic debate. ${ }^{130}$ The traditional way to start would be to connect to the sources that may be used by the International Court of Justice (ICJ). Article 38(1)(d) of the Statute of the ICJ leads us to the possibility of viewing EU law as a subsidiary source of international law. As we have seen, it is not that problematic to argue that the EU Treaties themselves are a source of international law, as 'treaties' are mentioned in Article 38(1)(a) of the ICJ Statue. In the same vein, international agreements concluded by the EU would fall under that heading. The question, then, is whether this implies that everything that is decided on the basis of the Treaties may also be seen as a source of law. In general, Decisions of international organizations are more frequently accepted as a source of international law (apart from the influence they may have on the development of customary law). ${ }^{131}$ Obviously, within the organization there should be no doubt as to the law-making nature of a decision. Thus, formal decisions taken by the EU institutions certainly count as ('secondary') law. The question of whether these decisions also have extraterritorial effects has briefly been addressed above in an affirmative sense. Yet, one may argue that these 'external' effects relate to the fact that a third State chooses to operate in relation to the EU's jurisdiction - be it by accessing the EU internal market or by 'connecting' to the EU's jurisdiction (think of air passenger rights). As a formal source of international law, EU secondary law therefore seems to have a limited effect.

(http://www.sdshhlaw.com/pdfs/European\%20Commission\%20on\%20Behalf\%20of\%20t he $\% 20$ European $\% 20$ Union $\% 20$ (Revised).pdf).

${ }^{129}$ See among the many publications on this case for instance G De Búrca, 'The European Court of Justice and the International Legal Order After Kadi' (2010) 51 Harvard International Law Journal 1-49.

${ }^{130}$ See for a recent analysis: H Thirlway, The Sources of International Law (OUP 2014).

${ }^{131}$ Ibid, 21-23. 
One avenue could be formed by the 'general principles of law' mentioned in Article 38 of the ICJ Statute. While these are to be 'recognized by civilized nations', it could be argued that the general principles of EU law 'as they result from the constitutional traditions common to the Member States' (Article 6(3) TEU) are therefore also recognized by these 'nations' (leaving aside for the moment the question of their 'civilization'). Again, specific references to general principles of EU law as sources of international law are hard to find.

As far as judgments by the Court of Justice of the European Union (CJEU) are concerned, we have noted that they are at least, occasionally, referred to by other international courts; yet not by the ICJ. However, when EU law is referred to by international judiciary bodies, such as in the case of WTO panel or Appellate Body, references to EU law are not used to interpret or develop international law, but mainly to explain EU law as such. In a formal sense, it is important to underline that the traditional sources doctrine ${ }^{132}$ does not give room to CJEU case law to function as an international law-making tool. Obviously, Article 38 of the ICJ's Statute refers to 'judicial decisions' as a source, which indeed provides for a possibility of the CJEU to influence ICJ judgments. As we have seen, however, this has not yet occurred in practice. When regarded in a broader sense, CJEU case law may of course influence general thinking on international law, as evidenced in particular by the Kadi saga.

\section{Conclusion}

A first question in reaction to all of the above could very well be in which sense the role of the European Union differs from the one States have in relation to the development of international law. Indeed, larger States in particular may be more influential and a similar analysis could be made (and has been made) in studies on the influence of, let's say, the United States on the development of international law. ${ }^{133}$ Yet, as we have seen, the nature of the European Union as a non-State actor that nevertheless participates among States, almost on an equal basis,

\footnotetext{
${ }^{132}$ It goes beyond the scope of this contribution to discuss the debate on the sources doctrine. See for instance J d'Aspremont, Formalism and the Sources of International Law (OUP 2011); AT Guzman, How International Law Works: A Rational Choice Theory (OUP 2008); or the attempts to square 'new' forms of international law with the sources doctrine: M Goldmann, 'Inside Relative Normativity: From Sources to Standard Instruments for the Exercise of International Public Authority' (2008) 9 German Law Journal 1865-1908, as well as DWP Ruiter and RA Wessel, 'The Legal Nature of Informal International Law: A Legal Theoretical Exercise', in J Pauwelyn, RA Wessel and J Wouters (eds.), Informal International Lawmaking (OUP 2012), 162-184.

${ }^{133}$ Examples include SV Scott, International Law, US Power: The United States' Quest for Legal Security (CUP 2012); M Byers and Nolte (eds.), United States Hegemony and the Foundations of International Law (CUP 2003).
} 
differentiates the question in the present study from other studies. At the same time, it has been less evident that international organizations contribute to the development of, for instance, customary law. And, when EU Member States act in the international legal order they still have their EU membership at the back of their minds, which may offer the EU an indirect way to influence international legal rules and principles. Indeed, State practice may be organizational practice in disguise, in particular when States act as agents of the EU in areas in which they have transferred their powers to the Union.

It may nevertheless not come as a surprise that the formal contribution by the EU to international law-making is limited. True, the normative influence of the EU is as undeniable as its visibility during many major international law-making events. As Hoffmeister argued: 'As a rule of law based organization, the EU attaches great importance to the correct application of existing international law...It...supports the jurisprudential strain of international law, strengthening its authority as a whole'. ${ }^{134}$ Indeed, the strengthening of international legal principles is visible in varying areas related to the prohibition of the use of force, international humanitarian law, non-proliferation of weapons of mass destruction, the fight against terrorism, human rights, international criminal law, economic law, international development, and environmental law. ${ }^{135}$

Yet, contributions that lead to an actual further development of (new) norms are less easy to find. One may argue that they may include the positions of the EU on jurisdiction, its efforts to participate (on a 'State-like' basis) in international organizations and to multilateral conventions, and - indirectly perhaps - its contributions to the work of the ILC. Even less measurable ${ }^{136}$ is the substantive influence of the EU in cases where it presents its normative values during the negotiations of (bilateral as well as multilateral) international agreements.

The 'otherness' of the EU seems to be a major explanation of the limited number of references to EU law and the fact that it is rarely accepted as a source of international law. ${ }^{137}$ The recent discussion on the accession of the EU to the European Convention on Human Rights only testifies to that and underlines once more that the EU cannot easily be fitted into other systems of international law. ${ }^{138}$ It simply doesn't fit in too well. ${ }^{139}$

\footnotetext{
${ }^{134}$ Hoffmeister (n 12) at 96.

${ }^{135}$ Ibid.

${ }^{136}$ Although political science and IR studies have certainly contributed to the notion that the EU has a normative impact on global governance. See references above (n 11).

${ }^{137}$ Cf. also Nevill (n 7) at 286.

${ }^{138}$ Lazowski and Wessel (n 73)

${ }^{139}$ Eckes and Wessel (n 116)
} 
This, in turn, underlines the idea that the EU's 'shaping of the international legal order' is not only done through the exporting of norms and values, but also (and occasionally perhaps even primarily) through forcing the international legal order to accept the EU as a new and relevant legal entity and to adapt its rules accordingly. And, we have to agree with Odermatt that ' $[t]$ he two modes are of course closely linked. In order for the EU to have an impact on the international legal order (direct shaping) it finds itself needing to play a greater role as an international actor in its own right'. ${ }^{140}$

Perhaps the 'otherness' or 'specialness' of the EU in itself as well as its effect on the 'Statehood' of EU Member States may be the most visible contribution to, at least, the practice of international law. In a way, the fact that EU Member States have lost considerable powers, as a result of the development of the EU as a global actor, may even have negative consequences for the development of international law. Due to their internal EU obligations, their 'state practice' is limited to those areas not covered by EU law and the fact that Member States are restraint by EU law obligations when exercising their external powers is part and parcel of their EU membership (including the way in which they, for instance, are to give effect of UN Security Council resolutions). At the same time, international law has, to a large extent, been replaced by EU law in relations between the Member States, allowing the European Court of Justice to apply EU law qua international law. ${ }^{141}$

First of all, this implies that - as we have seen - 'State practice' may not only be presented by states anymore, but by the EU, triggering the question whether the practice of international organizations is equally relevant to the development of customary law as the practice of States. Secondly, in a more substantive sense, the outcome of the intra-EU decision-making process may be a far less richer contribution to the development of international law than the various opinions and actions by individual States. Using the example of international environmental law, it has even been held that '[ $t$ ]he fettering of member states' ability to act unilaterally under mixed treaties works against the development of international law insofar as it can lead to a lower standard of protection under international

\footnotetext{
${ }^{140}$ Odermatt (n 7) at 20.

${ }^{141}$ And, at the same time, other tribunals may have to take into account EU law when dealing with international law issues between Member States. See for instance the Iron Rhine Arbitration between Belgium and The Netherlands, where the Permanent of Arbitration was "to render its decision on the basis of international law, including European law if necessary", but where the parties stated that "although the core of the present dispute related to questions not of EC law but international law, they would, if necessary, take all measures required to comply with their obligations under EC law, in particular under Article 292 of the EC Treaty [currently Art. 344 TFEU]". See Award in the Arbitration regarding the Iron Rhine ("IJzeren Rijn") Railway between the Kingdom of Belgium and the Kingdom of the Netherlands, decision of 24 May 2005, Reports of International Arbitral Awards, Volume XXVII, pp. 35-125.
} 
environmental treaties, the closing-off or watering-down of international debate under environmental treaty regimes, and the prevention of member states from assuming treaty obligations towards third states'. ${ }^{142}$

Yet, as we have seen, influence is not to be equated with forming an actual source of international law. This study has revealed that the formal reception of EU law in the international legal order is limited. While from an internal EU perspective this may come as a surprise, that should not be the case from an international law perspective. As held by Odermatt, ' $[\mathrm{t}] \mathrm{o}$ the international lawyer the EU Treaties and EU law are res inter alios acta, relevant and applicable only to the EU Member States and within the EU legal order. When the EU enters the international stage, this law is as relevant to international law as the internal constitutional law of a state'. ${ }^{143}$ Indeed, despite the EU's global normative ambitions, its very specialness seems to form an obstacle to contribute to international law-making in any formal sense, irrespective of the 'formative influence' it undoubtedly has in a more substantive sense.

${ }^{142}$ Nevill (n 7) at 294.

${ }^{143}$ Odermatt (n 7). at 293. 